\title{
Fenomen nauczania w świetle refleksji pedagogicznej Maxa van Manena i przedstawicieli współczesnej fenomenologicznej tradycii w edukacji
}

\author{
The Mastery in Teaching in the Light \\ of Pedagogical Thought of Max an Manen \\ and Representatives of Contemporary \\ Phenomenological Traditions in Education
}

\begin{abstract}
ABSTRAKT
Artykuł jest próba prezentacji osiqgnnięć w zakresie teorii wychowania Maxa van Manena, profesora Uniwersytetu w Albercie (Kanada), jednego z czołowych przedstawiciel pedagogiki fenomenologicznej. Podięto w nim próbę przybliżenia jego refleksji skupionych wokół procesu nauczania. Problematyka artykułu jest skoncentrowana na odkrywaniu znaczenia doświadczenia w procesie nauczania. Refleksje Maxa van Manena zostały zaprezentowane na tle rozwijajqcych się w tym obszarze badań prowadzonych w Europie i na świecie $w$ tradycji human science research $i$ w odniesieniu do najbardziej znanych badaczy podejmujacych problematykę, takich jak: Tone Saevi, Norm Friesen, Steven R. Smith, Cathrine Adams czy Gert Biesta.
\end{abstract}

SLOWA KLUCZOWE Max van Manen, fenomenologia praktyki, nauczanie, fenomenologiczna tradycja w edukacji

KEYWORDS

Max van Manen, phenomenology of practice, teaching, phenomenological traditions in education

SPI Vol. 24, 2021/3

ISSN 2450-5358 e-ISSN 2450-5366 DOI: 10.12775/SPI.2021.3.003

Nadesłano: 30.06 .2021 Zaakceptowano: 8.10.2021

Artykuły i rozprawy 


\section{ABSTRACT}

The article is an attempt to present the achievements in the field of theory of education of Max van Manen, professor emeritus of University of Alberta (Canada), who is regarded as one of the leading representatives of phenomenological pedagogy in the world. An attempt was made to present his reflection on the teaching process. The subject of the article is focused on discovering the meaning of experience in the teaching process. The reflection of Max van Manen is presented against the background of the research carried out in this area in Europe and in the world in the tradition of human science research and in relation to the most famous researchers dealing with the issues, such as Tone Saevi, Norm Friesen, Steven R. Smith or Gert Biesta.

\section{Wprowadzenie}

Prezentowane poniżej refleksje stanowią próbę wyjścia naprzeciw wyraźnie obserwowanemu rozwojowi nowych inspiracji badawczych w obszarze pedagogiki fenomenologicznej, jak i tych, które bezpośrednio odnoszą się do koncepcji relacji pedagogicznej oraz edukacji. Są one efektem prowadzonych przez autorkę badań, mających na celu przybliżenie polskiemu czytelnikowi myśli pedagogicznej jednego z wiodących przedstawicieli pedagogiki fenomenologicznej na świecie. Już na wstępie warto podkreślić, że wkraczając w świat myśli pedagogicznej Maxa van Manena oraz skupionego wokó jego idei środowiska badawczego wkraczamy $\mathrm{w}$ świat human science pedagogy, która koncentruje się na takich pedagogicznych tematach jak takt pedagogiczny, charakter, natura szkoły i klasy, autobiografia jako droga stawania się (currere), egzystencjalne aspekty edukacji i pedagogicznej relacji. Interesującą próbę syntezy osiągnięć buman science pedagogy w tym zakresie przedstawia Norm Friesen (Friesen 2020: 307-322). Nauczyciel, nauczanie i jakość nauczania, powiązane $z$ problematyką profesjonalizmu i refleksji nad sensem edukacji, często są eksplorowane we współczesnej fenomenologicznej tradycji w pedagogice. Jak podkreśla Gert Biesta, istotę nauczania tradycja ta postrzega jako pedagogiczną troskę o dziecko/młodą osobę jako unikatową i niemożliwą do zastąpienia. Kładzie ona mocny akcent na relacyjne, kulturowe i interpretatywne kwestie edukacyjnej praktyki 
i badań (Biesta 2012: 35-49). Fenomenologiczna tradycja w refleksji nad edukacją nie czyni wyraźnego rozróżnienia między profesjonalną praktyką a badaniami - zarówno jeden, jak i drugi obszar są częścią doświadczanego w relacji, poddanego interpretacji, wpisanego w strukturę znaczeń i wartości pedagogicznego działania. Wiedza o edukacji zaczyna się rodzić wraz z zainteresowaniem subiektywnym, żywym doświadczeniem, z którym spotykamy się w ciągu naszego codziennego życia z dziećmi. To spontaniczna zdolność wpisana w pedagogiczną intencjonalność, która odróżnia dobro od zła i pozwala nauczycielowi wybrać najodpowiedniejszy w danej sytuacji rodzaj działania. $Z$ autorytetem nauczyciela mamy do czynienia dopiero wtedy, kiedy dziecko zechce go „usankcjonować” i do tej roli samo go „upoważnić” (Levering 2011). Zależy on również od poziomu refleksyjności w i nad osobistym spotkaniem z dzieckiem (Van Manen 1995).

Max van Manen i Cathy Adams wskazują, że badania pedagogiczne nie mogą być traktowane jako odseparowane od życia, mają być raczej postrzegane jako sposób i szansa na to, by życiu się przyjrzeć (Adams 2010). Wkład w teorię wychowania, jaki może wnieść rozumiana fenomenologicznie subiektywna refleksja, ma umożliwiać ontoepistemologiczny wgląd w pedagogiczną praktykę i, jak podkreśla van Manen, pozwolić na poszukiwanie pedagogicznej i edukacyjnej alternatywy dla generalizujących wniosków tradycyjnie rozumianych procedur badawczych. We współczesnych badaniach nad edukacją taki pogląd można odnaleźć zarówno w poglądach autorów eksponujących polityczny wymiar badań nad edukacją, takich jak Gert Biesta, jak również u badaczy, których zainteresowanie wzbudza metodologia hermeneutyczno-fenomenologiczna (np. Tone Saevi). Artykuł tej ostatniej badaczki, Lived Relationality as the Fulcrum for Pedagogical-Ethical Practice (2011), podkreśla aporetyczny charakter pedagogicznej praktyki i teorii i wskazuje, że to relacja pedagogiczna tkwi w centrum refleksji nad wychowaniem i edukacją. To właśnie ta relacja może nas otworzyć na etyczne i egzystencjalnie normatywne pytania, a nie tylko na takie, które na przykład wynikają z norm rozwoju psychobiologicznego (Saevi 2011: 455-461). Jak zatem pokonać dystans od socjoekonomicznych celów wyznaczanych edukacji do egzystencjalnej relacji ze sobą, innymi i światem? 
Max van Manen podkreśla, że aby móc zacząć rozmowę o nauczaniu jako działaniu ze swej istoty pedagogicznym, musimy uważnie rozróżnić pomiędzy pedagogiką rozumianą jako obszar badawczy wspierany przez epistemologie stojące $u$ jej podstaw, związane $z$ dziedzinami takimi jak psychologia, socjologia czy filozofia, a pedagogiką z jej własną teorią opartą na pedagogicznym podejściu do fundamentalnych kwestii w obszarze wychowania i edukacji. Badania nad edukacją włączają w swój obszar edukację nieformalną i formalną, które mają miejsce domu, instytucjach społecznych czy szerzej - w społeczeństwie. Wymagają one antropologicznego i ontoepistemologicznego zainteresowania rzeczywistością pedagogiczną, co pociąga za sobą raczej potrzebę wypracowania metodologii niż konkretnych metod. Ten rodzaj metodologii zakłada konieczność przyjmowania postawy refleksyjnej. Dopiero ona nada badaniom kierunek i pozwoli wypracować odpowiednie metody. Badania edukacyjne mają na celu zachowanie lub ujawnianie prawdziwego znaczenia pedagogicznej teorii i praktyki. Problematykę tę rozwijają Norm Friesen, Carina Henriksson i Tone Saevi w książce Hermeneutic Phenomenology in Education (2012). Według nich głównym celem pedagoga staje się coraz głębsze rozumienie znaczenia, które kryje w sobie konkretna pedagogiczna sytuacja. Tu przychodzi z pomocą fenomenologiczna orientacja na żywe, konkretne doświadczenie partykularnej sytuacji wychowawczej.

Willfried Lippitz i Bas Levering sugerują, że profesjonalne nauczanie wnosi coś nowego do sytuacji. Zakłócenia i ingerencje, które do procesu nauczania wkraczają z zewnątrz, wywołują opór zarówno w uczniach, jak i nauczycielach (Lippitz, Levering 2002: 205-213). Ten kontekst refleksji nad nauczaniem jest dziś szeroko rozwijany w refleksji pedagogicznej. Catherine Adams postrzega istotę procesu doskonalenia się w nauczaniu w pedagogicznej odpowiedzialności za relację pomiędzy nauczycielem, uczniem, nowoczesną technologią służącą nauczaniu - wszystko to ma się stać przedmiotem uważnego etycznego zainteresowania i praktycznej etycznej troski (Adams 2010: 1-11). Ramy dla współczesnych badań prowadzonych w perspektywie fenomenologicznej tradycji w edukacji są zatem zakreślone bardzo szeroko. 


\section{Nauczanie jako działanie pedagogiczne}

Jak dziś pojmujemy termin „edukacja”? Omawiana tradycja badawcza kładzie główny akcent na towarzyszenie dziecku, bycie z dzieckiem w taki sposób, który zapewni właściwy kierunek i opiekę jego życiu i rozwojowi. Pokazuje, że educare to naprawdę prowadzenie. Pedagogiem jest ten, kto wchodzi w opartą na trosce i odpowiedzialnej opiece relację z dzieckiem. Idea prowadzenia i przewodnictwa tutaj oznacza więc branie za rękę, wsparcie, zachętę, rozumienie doświadczenia dziecka i empatię, odpowiedzialność oraz dzielenie się własnym doświadczeniem (Van Manen 1991: 38). Chcąc zrozumieć pojęcie i znaczenie pedagogiki, potrzebujemy coraz głębszej świadomości, że każdy musi „wyrosnąć” ze świata dzieciństwa, wszak educare to także „wyprowadzać z”. $Z$ drugiej strony świat mojej dorosłości staje się zaproszeniem dla dziecka - educare oznacza również „wprowadzać w”. Powadzić, to iść naprzód, jako pierwszy „badać teren”. Oznacza to stanąć jako dorosły w takim miejscu, w którym mam prawo powiedzieć: możesz mi zaufać, sprawdziłem/łam ten lód, wiem coś o radościach i pułapkach, o byciu „traperem” w podążaniu w stronę dorosłości i budowaniu świata - świata własnego życia. Jednak moje podążanie naprzód nie jest gwarancją twojego sukcesu, ponieważ świat nie jest pozbawiony niebezpieczeństw i zagrożeń. W relacji pedagogicznej jest miejsce na znacznie bardziej fundamentalną relację: Bez względu na wszystko jestem tu i możesz na mnie liczyć. W tym sensie znaczenie pedagogiki jest jeszcze bardziej fundamentalne niż to, które odsłaniają jego greckie korzenie. Wskazywanie dzieciom kierunku, zapewnianie im opieki i ochrony, to fundamentalne cechy dorosłego życia (Van Manen 1991: 38). W taki właśnie sposób Max van Manen zarysowuje w swojej refleksji pedagogicznej istotę nauczania.

W twórczości Maxa van Manena mamy do czynienia z ciekawym spotkaniem idei obecnych u przedstawicieli różnych dróg pedagogicznego myślenia. Wśród nich są ci, którzy postrzegają pedagogikę zasadniczo jako pole naukowych studiów, wyrażając przekonanie, że najważniejsze są podstawowe fakty i empiryczna wiedza, będąca owocem badań naukowych związanych z procesami uczenia się i rozwoju dziecka, a dotycząca warunków, które go utrudniają lub wspierają. Wśród nich są także ci, którzy widzą w pedagogice przede 
wszystkim moralny wysiłek i wierzą, że fundamentalne wartości, cele, normy i zasady są fundamentem pedagogicznego działania, a określenie, które wartości są tu istotne to etyczne, polityczne i społeczne przedsięwzięcie (Van Manen 1991: 38). Trzecią grupę stanowią ci, którzy uzależniają sukces pedagogicznej aktywności głównie od metod i metodologii związanych $z$ programem nauczania i jego wymiarem ,instruktażowym”. W końcu mamy do czynienia także i z perspektywą, która argumentuje, że działanie pedagogiczne w rzeczywistości zależy od filozoficznego rozumienia życia, ludzkiej egzystencji i kondycji, filozofii edukacji i rozumienia ludzkiej natury (Van Manen 1991: 38).

Chcąc zrozumieć na czym polega mistrzostwo w nauczaniu, należy najpierw zadać pytanie o znaczenie samego terminu „pedagogika”. Co ono dla nas dzisiaj znaczy? Max van Manen używa pojęcia pedagogiki, aby ominąć cały szereg założeń i kryteriów, mających przybliżać nam kwestie związane $\mathrm{z}$ edukacją. Jeśli ograniczymy się jedynie do tradycyjnej terminologii, pozostaniemy hermetycznie zamknięci wewnątrz tych sposobów rozumienia fenomenu edukacji i wychowania. Spowoduje to ograniczenie naszej refleksji i praktyki tylko do pewnych tradycyjnych kwestii. To nie oznacza, że są one nieistotne, by ich nie uwzględniać i nie rozważać. Max van Manen używa pojęcia pedagogiki jako klucza umożliwiającego otworzenie drzwi do innych zjawisk tworzących kształt i tożsamość współczesnego świata edukacji, takich jak pedagogiczne rozumienie, takt, pedagogiczna sytuacja i relacja (Van Manen 1991: 28).

Pojęcie pedagogiki, podkreśla van Manen, ma dzisiaj coraz szersze znaczenie, ale jego charakterystyczny sens jest zamazany, nieostry. Pedagogika jest coraz bardziej arbitralnie utożsamiana $z$ nauczaniem, programem nauczania, zarządzaniem edukacją. To pojęcie służy odnoszeniu się do specyficznych ujęć lub metodologii, obecnych w literaturze dotyczącej dydaktyki i programów nauczania. Kiedy uświadomimy sobie powiązania tego pojęcia z kontekstem społeczno-politycznym i filozoficznym oraz „eksplozją” odwołań do koncepcji takich jak pedagogika emancypacyjna, krytyczna, dekonstruktywna, musi się pojawić pytanie o to, w jaki sposób pojęcie pedagogiki ma się wyróżniać spośród tych specyficznych kategorii (Van Manen 1991: 28). Pytanie to van Manen stawia bardzo wyraźnie. 
W perspektywie tzw. phenomenology of practice van Manena i w refleksji kontynuatorów jego myśli oraz przedstawicieli skupionego wokół niego środowiska naukowego, edukacja to złożone pojęcie, odsłaniające różne znaczenia. Niektóre z nich wskazują na bliskie pokrewieństwo z pojęciem pedagogiki. Jak jednak należałoby je bliżej zdefiniować? Max van Manen wybiera termin „pedagogika”, aby podjąć próbę przekroczenia zagrożeń obecnych we współczesnym dyskursie o edukacji. Postuluje w związku z tym: (1) odrestaurować zapomnianą lub nieobecną relację między dorosłymi i dziećmi oraz (2) usunąć choćby niektóre z barier, które chronią współczesną myśl edukacyjną przed byciem w istocie myślą wychowawczą (Van Manen 1991: 130). Idąc dalej, wskazuje na konieczność dowartościowania relacyjnego i etycznego wymiaru nauczania, co ma umożliwić powrót do właściwego rozumienia takich pojęć jak pedagogika, takt pedagogiczny, pedagogiczna relacja. Ostatecznie ma to służyć coraz lepszemu dostrojeniu się do rzeczywistej relacji między dorosłym i dzieckiem. Jak pisze, konkretyzacja jego koncepcji pedagogiki nie jest niespójna $\mathrm{z}$ wieloma aspektami obecnymi w długiej, historycznej tradycji pedagogiki europejskiej. Nowy język pedagogiki nie może się odnosić jedynie do techniki nauczania, produkowania celów nauczania, programów i związanych z nimi kompetencji. Jego źródło tkwi w głębokim przekonaniu, że pedagogika w jej współczesnym rozumieniu musi mieć do czynienia przede wszystkim z osobowymi, relacyjnymi i etycznymi aspektami nauczania oraz wychowania dzieci i młodzieży. Taką ma być pedagogika nauczania, rodzicielstwa, relacji międzypokoleniowej, słowem - pedagogika każdej formy troski o dziecko (Van Manen 1991: 140).

Max van Manen zwraca uwagę, że współcześnie pedagogika przeradza się często w jakąś formę psychologii i tak jest traktowana. To, że psychologia rozwojowa pokazuje - przykładowo - iż dziecko jest w stanie się nauczyć czytać w bardzo wczesnym wieku, nie przesądza jeszcze, że powinno się uczyć tak wcześnie czytać, zwłaszcza że proces ten może się odbywać kosztem mówionej, dialogicznej aktywności w relacjach z innymi (Van Manen 1991: 48). W procesie werbalnych interakcji z innymi dziecko uczy się chociażby wymieniania się rolami, argumentacji, ekspresywności i relacji opartej na rozmowie. Poza pojedynczym doświadczeniem związanym z czytaniem, to właśnie one mogą zostać uznane za pedagogicznie istotne. 
W tym sensie pedagogika jest dyscypliną niezależną. Inne dziedziny nauk humanistycznych i społecznych mogą otworzyć nam dostęp do empirycznych, naukowych, politycznych i etycznych pytań o rozwój dziecka, zdrowie i chorobę w życiu dziecka, o znajomość prawa tam, gdzie mamy do czynienia z młodzieńczą przestępczością itp. Ostatecznie jednak żadna $z$ dyscyplin nauk humanistycznych i społecznych nie jest w stanie nam powiedzieć, co mówić i jak działać z dzieckiem w konkretnej sytuacji. Nie można tracić z oczu autonomii pedagogiki jako profesjonalnej praktyki i teoretycznej zarazem dyscypliny, jako szczególnego rodzaju etyki włączającej i angażującej dziecko (Van Manen 1991: 48). Mając tego świadomość, nie możemy tracić $\mathrm{z}$ oczu podstawowej intuicji, że nauczanie jest działaniem ze swej istoty pedagogicznym.

Nauczyciel potrzebuje filozoficznej i etycznej refleksji nad fenomenem człowieczeństwa. Jest on w najgłębszym sensie rozumienia tego słowa obserwatorem dziecka. Nie jest iluzją stwierdzenie, że jest on w stanie widzieć dziecko w sposób „czysty”, powstrzymując wszelki wpływ filozoficznego spojrzenia na to, co to znaczy być człowiekiem. Nie mogę adekwatnie postrzegać dziecka bez refleksji nad sposobem w jaki, patrząc na nie, postrzegam człowieczeństwo i ludzkie doświadczenie. Nauczyciel musi się otworzyć na doświadczenie obserwacji pedagogicznej - na dostrzeganie i umiejętność utrzymywania w polu widzenia całościowego obrazu egzystencji rozwijającego się dziecka (Van Manen 1991: 63).

Max van Manen mocno podkreśla, że w obrębie obecnie dominującej tradycji badawczej praktyka nauczania rzadko jest problematyzowana i systematycznie dyskutowana jako działanie pedagogiczne (Van Manen 1991: 63). Mówiąc o odsłanianiu najgłębszego sensu nauczania, nie można tracić z oczu, że w codziennej praktyce nauczania zdecydowana większość podejmowanych przez nauczyciela działań i wypowiadanych słów ma znaczenie normatywne. Nie tylko cele, ale środki oraz używane metody mają wartość pedagogiczną i normatywną. W centrum refleksji stają pytania o to, co jest odpowiednim, a co mniej odpowiednim działaniem w konkretnej sytuacji, co powinno się powiedzieć, jakim tonem głosu, kiedy milczeć, jaki gest wykonać, jakie metody i techniki nauczania oraz ewaluacji są $\mathrm{w}$ danych okolicznościach bardziej właściwe z pedagogicznego punktu widzenia. To nieustanna sztuka wyboru: jaki rodzaj doświadczenia 
jest odpowiedni dla danej grupy dzieci, jaki poziom wymagań może być im stawiany? Mnożą się pytania o poziom presji możliwy do zaakceptowania, o rodzaj dyscypliny właściwy w danej sytuacji, o to, jakie oczekiwania mogą być niewłaściwe itp. Stajemy wobec problemu rozpoznania i uznania normatywnej, moralnej, etycznej natury nauczania (Van Manen 1991: 152-153). I właśnie to ona staje w centrum naszej refleksji.

\section{Pomiędzy technicznymi kompetencjami a improwizacyjnym mistrzostwem}

W swojej refleksji Max van Manen niejednokrotnie wskazuje na dwie drogi rozwijane w filozofii i naukach humanistycznych, które mogą być szansą restauracji normatywnego wymiaru w nauczaniu. Jedna z dróg wyłania się z etyki cnoty, drugą nakreśla świadomość roli narracji i anegdoty w moralnej refleksji i działaniu (Van Manen 1991: 156-161). Tradycyjnie określenie tego, co jest właściwym lub złym działaniem oznacza postrzeganie konkretnego działania z perspektywy nadrzędnych koncepcji etycznych, takich jak dobro, sprawiedliwość, równość, godność czy też dobrze rozumiany ideał demokracji. Etycy odwołujący się do koncepcji cnoty przypominają, że pytania o to, jak działamy w konkretnych sytuacjach, zazwyczaj nie znajdują odpowiedzi w abstrakcyjnych rozważaniach i analizie zasad moralnych, etycznych lub politycznych teorii. Tam, gdzie mówimy o działaniu podejmowanym z dziećmi i dla nich, ważny jest kontekst, wrażliwość pedagogiczna, zdolność do podejmowania pedagogicznej refleksji w działaniu i osobowość samego nauczyciela (Van Manen 1991: 156-161). Spotkanie zawsze jest potencjalnie jakimś „momentem pedagogicznym”. Bardzo często, jeśli nie zawsze, w naszym codziennym życiu z dziećmi musimy działać pod wpływem chwili. Doświadczenie pokazuje, że nie ma czasu usiąść wygodnie i celowo, strategicznie, racjonalnie, z moralnego punktu widzenia decydować, co należy czynić w zaistniałej sytuacji. Nawet wówczas, gdy jest czas na refleksję nad dostępnymi alternatywami i kierunkami postępowania, to moment pedagogiczny wymaga działania, nawet jeżeli w danej sytuacji polega ono na powstrzymaniu się od działania (Van Manen 1991: 154). 
Max van Manen przekonuje, że tradycyjne koncepcje etyczne dobra czy sprawiedliwości w niewielkim stopniu są możliwe do wykorzystania pośród tysiąca interakcji obecnych w profesjonalnym życiu pedagoga. Pedagog musi się zatem powoływać na bardziej konkretne normy, tak by podjęte działanie pedagogiczne realizowane było w sposób refleksyjny, by było podejmowane $\mathrm{z}$ taktem i z wrażliwością na doświadczenie dziecka, na to, czym ono jest dla samego dziecka. Właśnie takie działanie pozwoli mu zauważyć i zrozumieć jego trudności. Pedagog ma się stać kimś, kto jest zdolny do prawdziwego słuchania, dostrzegania unikatowości każdego dziecka, rozumienia jego lęków i bezbronności, do podejmowania wyzwań, do bycia wytrwałym i cierpliwym w procesie wspierania oraz wiarygodnym, godnym zaufania i dostępnym dla osoby powierzonej jego opiece (Van Manen 1991: 154). Greckie słowo areté, oznaczające doskonałość, odnosi się do tych cech osobowych, które czynią to konkretne życie wzorcowym w wymiarze etycznym lub które prowadzą do doskonałości. Ciekawym spostrzeżeniem jest to, że nie są one redukowalne do samych reguł czy zasad moralnych (Van Manen 1991: 155). Max van Manen zwraca uwagę, że starożytni Grecy konkretne cnoty uzasadniali na sposób narracyjny, wykorzystując opowiadanie, poezję, anegdotę, parabole, mit, teatr, wskazując na obrazujące je osoby czy działania jako przykłady lub modele. Jest to kolejny ważny drogowskaz, za którym podążając van Manen poszukuje własnej formy troski o restaurację wymiaru humanistycznego $\mathrm{w}$ pedagogice.

Max van Manen niejednokrotnie wraca do refleksji nad konsekwencjami stwarzającej podziały, a zatem niszczącej także osobowy i moralny wymiar nauczania, rozpędzonej dominacji rozumu instrumentalnego. Tego rodzaju dominacja wydaje się wszechobecna w naszym doświadczeniu (Max van Manen 1994: 154). Dominacja technologicznej racjonalności stanowi prawdziwe wyzwanie dla utrzymania nieinstrumentalnego rozumienia pedagogicznej natury nauczania (Max van Manen 1994: 154). W efekcie staje się ona źródłem podziałów wewnątrz nas samych, pomiędzy nami a naszymi dziećmi, pomiędzy nami samymi a światem. Nie można zaprzeczyć, że rodzice pragną skutecznych szkół, że dzieci wymagają skutecznych nauczycieli, ci zaś muszą posiadać zarówno techniczne kompetencje, jak i improwizacyjne mistrzostwo (sztukę, artyzm). Nauczanie zasadniczo nie jest jednak ani wiedzą, ani sztuką; nie jest ani technologią, 
ani estetyką - twierdzi van Manen (Max van Manen 1994). Nauczyciele nie powinni pozwalać, by ich relacją z podopiecznymi rządziła technologiczno-instrumentalna lub estetyczna orientacja. Raz jeszcze warto podkreślić: nauczanie jest sercem normatywnej praktyki pedagogicznej, w jej arystotelesowskim rozumieniu - jest doskonałością nauczania (Max van Manen 1994). I co najważniejsze, jest sercem normatywnej praktyki pedagogicznej, ponieważ jest relacją.

\section{W stronę pedagogicznej odpowiedzialności}

Warto zwrócić uwagę na rozwijające się dziś w Europie i na świecie nowe badania prowadzone w pespektywie fenomenologicznej i nawiązujące do tradycji human science research. Należy więc podkreślić potrzebę recepcji wyników tychże badań przez polską pedagogikę. Dla pedagogiki fenomenologicznej, kiedy przyglądamy się współczesnemu rozwojowi refleksji nad nauczaniem i pedagogiczną relacją, na nowo szczególnie istotna staje się dziś problematyka dzieciństwa, jego natura i doświadczenie. Jak twierdzi van Manen, fenomenologiczny wkład w edukacyjny wgląd w dzieciństwo oraz to, kim jest dziecko i jakie są jego doświadczenia z jego własnego punktu widzenia - wszystko to dostarcza koniecznej, ale często omijanej perspektywy również dla refleksji nad nauczaniem. W artykule Naming Childhood: No Order and No End (2002) Max van Manen stwierdza, że w refleksji nad dzieciństwem nie chodzi tylko o rozumienie samej jego natury, ale raczej o interpretację tej fenomenologicznej sfery, w jakiej się ono ujawnia; chodzi tu raczej o rozumienie okoliczności, sytuacji, wydarzeń i doświadczeń, w których niejako dzieciństwo się „pojawia”. Dzieciństwo nie jest po prostu konstruktem kognitywnym - to również złożony pedagogiczny imperatyw, który winien nam przyświecać kiedy mówimy o sposobie, w jaki widzimy, czujemy i odpowiadamy na wezwanie dziecka (Van Manen 2006: 14-38). We współczesnym rozwoju tradycji human science reasearch wyraźnie zaznacza się fenomenologiczno-psychologiczna perspektywa analizy fenomenu dzieciństwa. Przykładem tego jest książka Evy Simms The Child in the World: Embodiment, Time and Language in Early Childhood (Simms 2008).

Wilfried Lippitz zadał ważne pytanie o to, w jaki sposób my, jako dorośli, pamiętamy i rewitalizujemy swoje dzieciństwo w naszej 
interpretacji spotkania z dzieckiem, które właśnie przeżywamy (Lippitz 1986: 56-65). Egzystencjalno-fenomenologiczne jakości procesu edukacji i wychowania prowadzą w stronę koncentracji na żywym doświadczeniu troski, na autentycznym przeżyciu dziecka. Kierują się także w stronę tego aspektu doświadczenia dziecka, jakim jest jego cierpienie. Lippitz akcentuje alienację przeszłości i teraźniejszości dzieciństwa. Charles Fischer w artykule The Child's World of Play and Pain (1989) podejmuje refleksje nad tym, w jaki sposób zranienie zmienia świat życia dziecka, w jaki sposób dziecko radzi sobie w świecie bólu. To praca, która bada doświadczenie bólu dziecka. Opisuje swoistą „pedagogikę bólu”.

Fischer koncentruje się na różnicy pomiędzy wolnością zabawy i pasywnością w bólu (Fischer 1989: 106-113). Z kolei Kate Meyer-Drawe w artykule Kaleidoscope of Experiences: The Capability To Be Suprised by Children (1986) kieruje spojrzenie w stronę żywego doświadczenia fantastycznego dziecięcego świata, którego współdoświadcza człowiek dorosły. Ta publikacja poświęcona jest ważnemu dla zrozumienia dziecięcego doświadczenia „magicznemu światu”, który jest obecny w jego życiu. Co to znaczy być zaskoczonym przez dziecko? To doświadczenie może się okazać formą przeciwdziałania nawykom, które nabyły osoby dorosłe (Meyer-Drawe 1986: 48-56).

Max van Manen i Bas Levering w książce Childhood Secrets: Intimacy, Privacy and the Self Reconsidered (1996) postawili w centrum swojej refleksji sekret, prywatność, tajemnicę obecne w samym centrum codziennego doświadczenia dziecka. Van Manen zasadniczo opowiada się za edukacyjnym wyborem perspektywy dziecka, ucznia, wychowanka, studenta, podopiecznego. W artykule The Language of Pedagogy and the Primacy of Student Experience (1999) szczególne miejsce zajmuje refleksja nad językiem pedagogiki i prymatem doświadczenia dziecka/ucznia/studenta. Prymat ten ma duże znaczenie w procesie poszerzania i pogłębiania refleksyjności nauczyciela. Każde badanie fenomenologiczne w obszarze edukacji ma być formą pedagogicznej troski i potwierdzaniem dojrzałej decyzji o otaczaniu dziecka odpowiedzialną opieką (Van Manen 1999: 13-27).

We współczesnej literaturze przedmiotu podejmującej problematykę fenomenologii w edukacji obydwa te pojęcia (fenomenologia i edukacja) traktowane są jako wzajemnie się ze sobą przeplatające. Pozwala to nam wyjść poza różnorodność kulturowych, historycznych, 
tradycyjnych stanowisk badawczych w tym zakresie. Badacze próbują więc postrzegać fenomenologię i edukację w całym pluralizmie europejskiej tradycji, jakkolwiek ze swoistą krytyczną perspektywą wychodzącą na spotkanie historycznym i współczesnym dyskursom. O ile Max van Manen poddaje refleksji badawczej takt i refleksyjność jako bazowe jakości i uwarunkowania procesu edukacji, o tyle w sposób szczególny na edukacji jako badaniu codziennego życia koncentrują się Loren Barrit, Ton Beekman, Hans Bleeker i Karel Mulderij (1985). Wielość osobistych perspektyw i edukacyjnych credo poddaje Gert Biesta (2012). Niewielka książeczka Maxa van Manena The Tone of Teaching (2002) przedstawia refleksje nad znaczeniem pojęcia atmosfery dla edukacyjnej praktyki.

Carina Henriksson w książce Living Away from Blessings: School Failure as Lived Experience (2008) podejmuje ostrą krytykę tego, co przyniosły późne lata XX wieku i wczesne lata obecnego stulecia dla teorii i praktyki pedagogicznej w pracy z osobami o specjalnych potrzebach edukacyjnych. Swoją refleksję opiera na zakorzenionej w jej własnym doświadczeniu relacji z kruchymi młodymi osobami, które poddano edukacyjnemu wsparciu (Henriksson 2008). Bas Levering również podkreśla, że epistemologiczny punkt wyjścia, który wyraża się w łączącej nas intersubiektywności, w fenomenologii zastępuje obiektywizację, a wymaganie interpretacji świata życia jako przenikającej autointerpretację przeciwstawia się „tradycyjnemu” narracyjnemu materiałowi w badaniach jakościowych (Levering 2006: 451-463). To, co subiektywne, może być „inne”, nawet obce, trudne lub niemożliwe do ekspresji wobec dziecka lub dorosłego, jak wskazywał Lippitz (Lippitz 2003). Ta świadomość staje się apelem o odpowiedzialność osób dorosłych w sytuacjach związanych z edukacją.

Systematyczne studia nad kwestiami związanymi z edukacją podejmowane $\mathrm{w}$ perspektywie fenomenologicznej prowadzi Malte Brinkmann (Brinnkman 2010). Jej publikacja oraz publikacje innych autorów z nurtu tradycji fenomenologicznej w badaniach nad edukacją postrzegają profesjonalizm jako pedagogiczną troskę o dziecko i młodego człowieka jako unikatową i nie do zastąpienia, nie do „wymienienia” z niczym, najściślej związaną z relacyjnymi, kulturowymi i interpretacyjnymi kwestiami praktyki pedagogicznej i badawczej. Warto raz jeszcze podkreślić, że tradycja fenomenologiczno-pedagogiczna nie czyni wyraźnego rozróżnienia pomiędzy praktyką 
pedagogiczną a badaniami. Zarówno jedną, jak i drugą sferę doświadczenia pedagogicznego taktuje jako nośnik wartości, możliwy tylko w relacji, jako interpretatywną praktykę. Wiedza na temat wychowania i edukacji zaczyna się od subiektywnego, żywego doświadczenia, które jest naszym udziałem. To spontaniczna aktywność wbudowana w pedagogiczną intencjonalność, która rozróżnia dobro od tego, co dobrem nie jest, i która umożliwia nauczycielowi decydowanie o najlepszym właściwym działaniu (Van Manen1995: 33-50). Autorytet profesjonalnego nauczyciela, jak również rodzica, jest zależny od woli dziecka, by ten autorytet usankcjonować, jak chce Levering (Levering 2011: 109-123). Zależy on również od refleksyjności nauczyciela w osobistym spotkaniu z dzieckiem. Lippitz i Levering sugerują, że profesjonalny nauczyciel zawsze wnosi coś nowego do sytuacji pedagogicznej (Levering, Lippitz 2002: 205-213). Co więcej, zakłócenia i ingerencje, które przychodzą z zewnątrz, stawiają opór zarówno uczniowi, jak i nauczycielowi.

Catherine Adams podejmuje refleksje nad profesjonalnym nauczaniem i koncentruje się na pedagogicznej odpowiedzialności za relację pomiędzy nauczycielem, uczniem a nowymi technologiami w obszarze edukacji, dostrzegając w niej przede wszystkim obszar etycznej troski (Adams 2010). Ważnym wątkiem w literaturze fenomenologicznej jest również edukacja egzystencjalna. Edukacja we współczesnej refleksji fenomenologicznej ujmowana jest jako moralna orientacja w kierunku tworzenia relacyjnych jakości konkretnego, praktycznego działania oraz w budowania refleksji „nad” $i$ „w” praktyce. To umieszcza nauczyciela, dziecko i relację między nimi w samym centrum egzystencjalnego procesu nauczania. Egzystencja jest zawsze w sercu fenomenologicznej edukacji. Otto Bollnow mierzy się z pedagogicznym znaczeniem kryzysów życiowych. Koncentruje się na edukacji jako na braku ciągłości, jak i swoistej kontynuacji (Bollnow 1959). W pracy Crisis and Nerw Beginning: Contributions to Pedagogical Antbropology (1987) proponuje drobiazgową fenomenologiczną analizę kryzysu, śmierci i umierania, bezpieczeństwa, osoby i kształcenia oraz edukacji jako egzystencjalnego spotkania. Ukazuje bliski związek między pedagogiką a egzystencjalizmem (Bollnow: 1987). Levering z kolei w pracy Phenomenology and Existentialism (2010) pokazuje, w jaki sposób ludzka subiektywność kształtuje podstawę egzystencjalnej edukacji jako fenomenologicznego, antropologicznego wysiłku. 
To, z czym zostajemy, kończąc - a tak naprawdę rozpoczynając ów niedługi spacer ścieżkami refleksji proponowanej przez Maxa van Manena i współczesnych przedstawicieli tradycji buman science research oraz pedagogiki inspirowanej fenomenologią, to uparte przypominanie, że prawdziwym sensem pedagogiki jest dążenie do doskonałości. Rozwój świadomości pedagogicznej i pedagogicznych kompetencji staje się zatem naturalną częścią moralnego rozwoju. Potrzeba pogłębiania tej świadomości i kompetencji zdaje się być wręcz rozumiana na wzór arystotelesowskiego pojęcia cnoty. W tym sensie - jak mówi Max van Manen - pedagogika staje się cnotą. Stawia on również pytanie, czy przypadkiem nie popełniamy błędu kładąc znak równości pomiędzy pedagogiką a nauczaniem. Praktyka nauczania rzadko jest problematyzowana i systematycznie dyskutowana jako działanie pedagogiczne. Może warto się przy tym zatrzymać dłużej? Zatrzymać i zastanowić się nad poszukiwaniem wrażliwego etycznie języka i takiej epistemologii praktyki, która będzie głęboko zainteresowana doświadczeniem dziecka i sferą relacji między nim a dorosłym lub między dorosłym a osobą powierzoną jego opiece (Van Manen). $\mathrm{Z}$ pewnością warto.

\section{Bibliografia}

Adams C. (2010). Teachers Building, Dwelling, Thinking with Slideware, „Indo-Pacific Journal of Phenomenology”, t. 10, nr 1, s. 1-12.

Barrit L, Beekman T., Bleeker H., Mulderij K. (1985). Researching Educational Practice, Grand Forks (ND): Center for Teaching and Learning, University of North Dakota.

Biesta G. (2012). Making Sense of Education: Fifteen Contemporary Educational Theorists in Their Own Words, Dordrecht: Springer.

Bollnow O.F. (1959). Existenzphilosophie und Pädagogik: Versuch über unstetige Formen der Erziehung, Stuttgart: Kohlhammer.

Bollnow O.F. (1987). Crisis and New Beginning: Contributions to Pedagogical Anthropology, Pittsburgh (PA): Duquesne University Press.

Brinkmann M. (2010). Erziehung: Phänomenologische Perspektiven, Würzburg: Königshausen und Neumann.

Fischer Ch. (1989). The Child's World of Play and Pain, „Phenomenology + Pedagogy", t. 7, s. 106-114.

Friesen N. (2020). Education as a Geisteswissenschaft: An Introduction to Human Science Pedagogy, "Journal of Curriculum Studies”, t. 52, nr 3, s. $307-322$. 
Friesen N., Henriksson C., Saevi S. (2012). Hermeneutic Phenomenology in Education: Method and Practice, Rotterdam: Sense Publishers.

Henriksson C. (2008). Living Away From Blessings: School Failure as Lived Experience, London (Ont.): The Althouse Press.

Levering B. (2006). Epistemological Issues in Phenomenological Research: How Authoritative are People's Accounts of Their Perceptions?, "Journal of Philosophy of Education" t. 40, nr 4, s. 451-463.

Levering B. (2010). Phenomenology and Existentialism, [w:] International Encyclopedia of Education, t. 6, red. P. Paterson, E. Baker, B. McGaw, Oxford: Academic Press, s. 80-85.

Levering B. (2011). "The Interest of the Child" Seen From the Child's Perspective: The Case of the Netherlands, „Ethics and Education”, t. 6, nr 2, s. 109-123.

Lippitz W. (2003). Differenz und Fremdheit, Frankfurt am Main: Lang.

Lippitz W., Levering B. (2002). And Now You Are Getting a Teacher With Such as Long Name..., „Teacher and Teacher Education”, t. 18, nr 2, s. $205-213$.

Meyer-Drawe K. (1986). Kaleidoscope of Experiences: The Capability to Be Surprised by Children, „Phenomenology + Pedagogy”, t. 4, nr 3, s. 48-55.

Saevi T. (2011). Lived Relationality as Fulcrum for Pedagogical-Ethical Practice, „Studies in Philosophy and Education”, t. 30, s. 455-461.

Simms E. (2008). The Child in the World: Embodiment, Time, and Language in Early Childhood, Detroit (MI): Wayne State University Press.

Van Manen M. (1991). The Tact of Teaching: The Meaning of Pedagogical Thoughtfulness, London (Ont.): The Althouse Press.

Van Manen M. (1994). Pedagogy, Virtue, and Narrative Identity in Teaching, „Curriculum Inquiry”, t. 24, nr 2, s. 135-170.

Van Manen M. (1995). On the Epistemology of Reflective Practice, „Teachers and Teaching”, t. 1, nr 1, s. 33-50.

Van Manen M. (1999). The Language of Pedagogy and the Primacy of Student Experience, [w:] tegoż, Researching Teaching: Methodologies and Practices for Understanding Pedagogy, red. J. Loughran, London: Routledge, s. 13-27.

Van Manen M. (2002). The Tone of Teaching: The Language of Pedagogy, London (Ont.): The Althouse Press.

Van Manen M. (2002). Lecture 2: Naming Childhood: No Order and No End, [w:] The Phenomenology of Childhood: The Nineteenth Annual Symposium of the Simon Silverman Phenomenology Center, red. W. Lippitz, D.J. Martino, Pittsburgh (PA): Simon Silverman Phenomenology Center, Duquesne University, s. 14-38.

Van Manen M., Levering B. (1996). Childhood's Secrets: Intimacy, Privacy, and the Self Reconsidered, New York: Teachers College Press. 


\section{ADRES DO KORESPONDENCJI}

Dr Marta Krupska

Uniwersytet Pedagogiczny w Krakowie

Instytut Nauk o Wychowaniu

marta.krupska@up.krakow.pl 